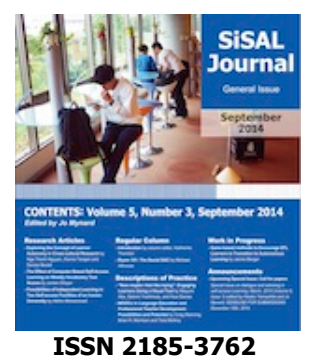

Studies in Self-Access Learning Journal

http://sisaljournal.org

\title{
Exploring the Concept of Learner Autonomy in Cross-Cultural Research
}

Nga Thanh Nguyen, Queensland University of

Technology, Australia

Donna Tangen, Queensland University of Technology, Australia

Denise Beutel, Queensland University of Technology, Australia

Corresponding author: nguyenngalisa@yahoo.com.vn

Publication date: September, 2014.

\section{To cite this article}

Nguyen, N. T., Tangen, D., \& Beutel, D. (2014). Exploring the concept of learner autonomy in cross-cultural research. Studies in Self-Access Learning Journal, 5(3), 202-216.

\section{To link to this article}

http://sisaljournal.org/archives/sep14/nguyen_tangen_beutel

This article may be used for research, teaching and private study purposes.

Please contact the authors for permission to re-print elsewhere.

Scroll down for article 
SiSAL Journal Vol. 5, No. 3, September 2014, 202-216

\title{
Exploring the Concept of Learner Autonomy in Cross-Cultural Research
}

Nga Thanh Nguyen, Queensland University of Technology, Australia

Donna Tangen, Queensland University of Technology, Australia

Denise Beutel, Queensland University of Technology, Australia

\begin{abstract}
This research explores how the concept of learner autonomy is understood and used in Vietnamese higher educational settings. Data were collected through interviews in Vietnamese with four university lecturers in Hanoi, Vietnam and then reported in an English language thesis. The problems confronted by the lecturers were in understanding the concept of learner autonomy, the complexities of translation equivalence for the concept from one language to another, and the impact of culture in interpreting the concept of learner autonomy. The paper concludes with recommendations for educators to be sensitive to cultural and linguistic considerations when transferring concepts from one culture to another.
\end{abstract}

Key words: learner autonomy, cross-cultural research, higher education, Vietnamese context

While various concepts and models have been introduced (mainly by Western researchers) into Asian contexts for quite some time (Yang, 2012), many of these concepts may be not only messy in their original contexts, but may also be contradictory to Asian cultural contexts. A better understanding of how or even if, such concepts can be used in different cultures needs further exploration. This research focuses on exploring the concept of learner autonomy in Vietnamese higher education, addressing the questions: How do Vietnamese lecturers understand the concept of learner autonomy? and How do Vietnamese lecturers incorporate the concept of learner autonomy in their pedagogy? As we will argue in this paper, before lecturers can enact beliefs about any learning concept (e.g. learner autonomy), they must first understand that concept. Without such understanding any idea introduced is unlikely to be taken up by lecturers, particularly a concept foreign in language and culture. This paper reports on three 
considerations: the complexities of the construct, the impact of cultural pedagogy, and translation equivalence of the construct of learner autonomy.

\section{Literature Review}

\section{Complexities of the construct of learner autonomy}

Learner autonomy has been described as a complicated construct and sometimes a multifaceted concept. Holec (1981) broadly defined learner autonomy as a learner's "ability to take charge of one's own learning" (p. 3). Since then, the concept has been modified and developed to suit particular research paradigms. For example, researchers have defined learner autonomy as 'capacity' (Little, 1991) or 'right' (Benson, 1997) as a substitute for the word 'ability' in Holec's (1981) definition. Others use terms like: 'take control of' (Benson, 1997), 'take responsibility for' or 'be responsible for' (Dang, 2010), instead of 'take charge of' as with Holec's original definition. Dang (2010) suggests that these changes seem to be "a matter of linguistics only, and the semantic aspects of the construct remain unchanged" (p. 5). The authors of this paper, however, contend that different definitions of learner autonomy change the nature of what is meant by the concept and these changes define how learner autonomy is subsequently understood and applied at the classroom level, especially when it is a new concept in a new context like Vietnam.

\section{The impact of cultural pedagogy}

The authors begin by acknowledging the diversity of Asian cultures, traditions and histories as unique to their local environments. It would be an oversimplification to talk about Asian cultures or contexts without also acknowledging the diversity of Asian cultures, traditions and histories. However, it is important to acknowledge that "a core set of common claims which include: respect for authority; acceptance of hierarchy; an orderly society loyalty to family and nation" (Knight, 2007, p. 46) are generally common cultural features of Asian countries. While there is a growing appreciation for the diverse cultures, languages and beliefs found in the Asian region there is also recognition that there are some similarities that cultures in this area of the world share, and these might be shared differently to how such customs are enacted in Western countries. Vygotsky 
(1978) suggests that every phenomenon has a history that changes in form and structure mediated through human-environment interaction. Education in Vietnam has been depicted as having traditional approach to teaching and learning. If concepts such as learner autonomy are taken into Vietnamese education by Western researchers, we must consider how the concept is introduced, by whom, and how it is constructed and deconstructed locally. According to Yang (2012), satisfactory discussion about incorporating concepts by Western researchers into Asian contexts is quite limited.

Pedagogy in Vietnam has begun to incorporate more concepts and practices used in other nations. However, it remains to be seen how these concepts mandated by the government are enacted in the classroom. For example, in Vietnam, the Ministry of Education and Training (Moet) is the only organisation that issues curricula for all educational systems. These top-down directives continue to be a strong feature in Vietnamese education and have guided the pedagogy of lecturers for many years. Generally, the content of learning, including objectives and activities/tasks that students undertake in class, is predetermined (Nguyen, 2010). Because of the bureaucratic constraints in the educational system, neither lecturers nor students are able to make pedagogical changes even if they are interested in doing so (Pham, 2006). By the same token it cannot be taken as a given that policies created by bureaucrats will be taken up as classroom practice. There is much recent research on resistance teachers put up when faced with change in various ways, such as curriculum change (Mutch, 2012) or professional development (Mohamed, 2008). Without a clear reason provided for change or support in helping teachers make changes, resistance can block the effective enactment of this change. The authors of the current paper suggest that introducing the concept of learner autonomy into policy without helping lecturers understand the concept and how to integrate it into their pedagogy might meet with resistance.

Traditional Asian culture in countries such as Vietnam influences lecturers' and students' beliefs that they have certain roles and responsibilities in the class and that they should follow the traditional way of teaching (Ho \& Crookall, 1995) which, until recently, has not included learner autonomy. Pham (2008), for example, argued that many teaching institutions have failed to replace the traditional teacher-centred approach used at Vietnamese higher education institutions partly because Vietnamese lecturers are not 
happy to transfer their roles from knowledge transmitters to learning facilitators. Recent approaches to teaching and learning, especially in English-as-a-foreign language (EFL) pedagogy, however, emphasise the role of learners as autonomous participants and place the lecturer as the facilitator in this process. This change in classroom dynamics is generally at odds and conflicts with Asian cultural practices (Dardjowidjojo, 2001). Little (1991) describes how lecturers in Asia believe the education system is "so all-powerful and inflexible that autonomous learning can never happen" (p. 40). It can be argued that this 'traditional' approach results in less negotiation or collaboration between lecturers and students and inhibits learner autonomy being incorporated as part of the classroom pedagogy.

\section{Difficulties of translation equivalence of concepts}

A critical concern about incorporating concepts into different cultures and contexts is translation equivalence. Sutrisno, Nguyen and Tangen (2013) describe the many complexities in translating a foreign-origin concept, such as learner autonomy, into a new language. While some sort of equivalence of understanding can be obtained, there are so many language and culture-specific factors in the process of translation that achieving absolute equivalence is likely unattainable (Baker, 2011). A word or a lexical item in the source language may have more than one equivalent in the target language and vice versa (Sutrisno et al., 2013). As indicated above, learner autonomy is a term that is not easy to define, and many different definitions of learner autonomy exist in the literature. The authors found that this situation was mirrored in the Vietnamese context where there were several different definitions of learner autonomy, as described below.

In educational documents in Vietnam, the phrase "tính tích cực, chủ động, năng lực tự học, tự nghiên cứu của người học" [Learners (characteristic of being) engaged and motivated in learning and capacity to learn on their own or without the support from the teacher] is used in a government document (Prime Minister, 2003, p. 7). "Ý thức tự giác trong học tập, năng lực tự học, tự nghiên cứu" [The characteristics and situation of being responsible for learning, the ability to learn on their own] is used in the law on education (Vietnamese Assembly, 2005, p. 12). It is important to note that in these two important educational documents, the terms with the word "tính" which refers to a learner's 
characteristics of being responsible for their learning, are favoured. In addition, the words “tự học tập" [learning on one's own] and "tự nghiên cứu” [self-study] are common in these two documents. The equivalent term for learner autonomy in Vietnamese that is generally used is "chủ động của người học" which is translated as "the autonomy of the learner". However, this translated term is too general to understand because it does not identify what dimension of learner autonomy is being discussed, which is necessary in Vietnamese. It is important to note that while the various meanings of the Vietnamese translations of learner autonomy as described above are bound to result in different interpretations of the term, identifying the specific perspective of Vietnamese language users through their word usage is paramount to understanding how they interpret the term in policy documents and in teaching practices. The problem may become more complicated for educators in certain Asian contexts where information to explore or clarify concepts, such as learner autonomy, are not easily accessible due to the lack of support or lack of access to up-to-date literature or databases in the field.

In summary, difficulties with the definition of learner autonomy, which may come from the translation equivalence of the construct and the cultural factors was considered in this research to explore Vietnamese lecturers' understanding of learner autonomy, and subsequently how they applied that learning to their pedagogy.

\section{Method for the Research}

This paper is part of a larger $\mathrm{PhD}$ project completed by the first author. This paper reports on data from interviews with four participants, Thu, Ngan, Bich, and Ha who were English-as-a-foreign language (EFL) lecturers at four large universities in Hanoi, Vietnam. Semi-structured interviews and classroom observations of teaching were conducted individually with each of the four participants. Initial interviews were conducted prior to classroom observations to get background information about the teachers' understandings of learner autonomy. Follow-up in-depth interviews were conducted after each classroom observation as stimulated recall interviews (SRI) (Calderhead, 1981). Video stimulated recall (VSR) is a research technique in which research participants view a video sequence and are then invited to reflect on their thinking during the video recorded event (Calderhead, 1981; Lyle, 2003). In general, the 
technique of stimulated recall gives participants a chance to view themselves in action in order to help recall their thoughts about what is happening on the screen. It is important to note that in order to enable the participants to express their views easily, the researcher invited them to choose the language they would like to use in the interviews. While all lecturers are teachers of English, all chose to be interviewed in Vietnamese. It has been suggested that the person doing the translation in cross-cultural research should be familiar with both the language and the culture of the participants (Liamputtong, 2010). Therefore, in the current study, the researcher was Vietnamese and also a lecturer in EFL in Vietnam, so she was familiar with the specific cultural context of the research. The data in this paper will focus on the teacher interviews.

All semi-structured interviews were transcribed and translated by the researcher (this process is presented in Sutrisno et al., 2013). Data were coded using a constant comparative method (Fram, 2013) which involves breaking down the text in the interview transcripts into themes, which were then refined to develop categories (Lapan, Quartaroli, \& Riemer, 2012). Lopez, Figueroa, Connor and Maliski (2008) suggested that it is imperative to transcribe qualitative interviews verbatim in the participants' language or source language, and then translate this script into the target language. Following this suggestion, the researcher transcribed all the interviews in Vietnamese by herself. Data presented in the paper was recorded verbatim as it was translated rather than going through another step of reworking the data into 'proper' English text. This decision attempts to present the most authentic voice of the participants as possible. In addition, during the interviews, the participants sometimes used English to express some phrases or terms as well as speaking in Vietnamese. Consequently, the transcripts contained a mixture of English and Vietnamese phrases. This led to the decision to translate all the interviews into the target language (English) before using NVIVO - data analysis software - because NVIVO cannot run in two different languages at the same time. In addition, according to Kvale and Brinkmann (2009), "interviewing is linguistic interaction, and the product of the interview is a language text. A linguistic analysis addresses the characteristic uses of language in an interview, the use of grammar and linguistic forms" (p. 6). In contrast, analysis of interview transcriptions focusing on meaning addresses the characteristic use of meaning inferred from the language. 
Therefore, the investigator first translated the interviews fully from Vietnamese into English using the single translation procedure, including some parallel translation (Vietnamese-English and English-Vietnamese) (see Sutrisno et al. (2005) for more information about the translation process as it is presented in this article). It was complicated to obtain the corresponding words for the term learner autonomy in Vietnamese, as mentioned above. The term can be translated into Vietnamese in different ways, and each version reveals the translator's connotation and perspective, which would have had an influence on the interviewees' perspectives and understanding. Therefore, in order to achieve as close as possible equivalence for the research, the researcher decided to keep this key term in the target language during her interviews. Three major findings from the research are described below. These include: the complexities of the construct of learner autonomy, the impact of traditional Vietnamese pedagogy, and the difficulties of translation equivalence.

\section{Findings from the Research}

\section{Complexities of the construct of learner autonomy}

There was a lack of understanding by the participants about the concept of learner autonomy, which may have been due in part to the complexities of the construct. The data from the current research indicated that all four participants interpreted learner autonomy differently. The word "tính" in Vietnamese refers to the characteristics or personality of a person. This interpretation indicates that learner autonomy is innate rather than learnt. For example, Ha defined learner autonomy as "tính tự chủ, chủ động, tự giác học của người học" [learner's characteristic of being responsible for learner's own learning]. The word "sự" or "việc" refers to the behaviour/situation of the person. For example, Ngan said "sự chủ động của người học trong việc tự học là chưa có trong đối tượng này" [the behaviour of being responsible for their own learning is not for the current students]. Both terms were used by the four teachers in the current research at various times for various reasons. Bich defined learner autonomy as "tính chủ động tức là tự học, tự mầy mò để học" [learners' ability to study on their own without teachers' support]. Other important words associated with learner autonomy are "negotiation" or "collaboration" which can be used to indicate the social perspective of the term. 
However, these words and phrases were not used by the four lecturers in the study. The most consistent interpretation of learner autonomy by participants in the current research was that of self-instruction, which means learning without a lecturer (Little, 1991) or learning without direct control of a lecturer (Dickinson, 1987). Clearly there is a need for an agreed understanding of what learner autonomy means if not in a global context, then certainly in the local context of Vietnam. The lack of agreement and understanding about the concept revealed in the current research suggests that there need to be some conversations in the Vietnamese higher education community about what is meant by the term 'learner autonomy' to clarify confusion.

\section{The impact of traditional Vietnamese pedagogy}

In the current research, participants appeared to be heavily swayed by traditional teaching practice and have yet to take up the practice of supporting the development of learner autonomy within their students. Mirroring Little's (1991) observation, participants in the current research described that the syllabus is so powerful that it determines everything a lecturer does in the classroom. This observation causes concern, as Little was writing about the culture of schooling in the 1990s. It would appear that not much has changed in Vietnamese teaching in the last thirty years, making the incorporation of concepts such as 'learner autonomy' problematic. In the current research, the participants stated that the strongest feature of curriculum hindering their fostering of learner autonomy was the role of centralised exams. All four lecturers described that the final-semester examinations determined the content of learning. In Vietnam, lecturers are assessed in terms of their learners' academic success, which is measured by learners' performance on exams; thus, learners' examination scores are indicators of lecturers' teaching quality (Pham, 2006). Understandably, then, lecturers have to teach to promote students' success in examinations. The participants in the current research indicated that success in mandatory testing was the supreme aim of every student and lecturer. In her final interview Thu stated:

Everything is test-oriented. All lessons must be very practical, understandable. In addition, the lessons must be more difficult than the real test. ... So, I have to give them enough proper topic-based tasks [such as more sentence-writing exercises or 
word-building exercises], not to let them to learn and construct themselves. (Thu, final interview)

The participants in this research indicated that learner autonomy was not prioritised as a particular pedagogy in their classes. Their focus was to assist students in achieving satisfactory results on exams, rather than assist them in becoming autonomous learners. They stated that they needed to control the students and the lesson by giving the students activities to do in the class. Indeed, the participants in the current research expressed great reluctance to hand over any of the learning process to their students because they did not feel that students were capable enough to take on autonomous learning. In addition, there was a feeling expressed that allowing students autonomy in their learning would take away time for more important activities, such as preparing for exams. Bich commented, "I didn't let my students prepare the activities because they couldn't do as I expected them to do and, as a result, we wouldn't meet the objectives of the lesson. Also, it would take more time".

Ngan and Thu, who both had some training on new approaches to teaching, including the concept of learner autonomy, believed that their current students would not become autonomous in their classrooms because the students did not have the capacity or motivation to become autonomous. None of the four lecturers felt responsible for facilitating the development of learner autonomy. Implementation was hampered by lecturers' lack of understanding of the concept of leaner autonomy; it would be difficult for them to apply a pedagogy they knew little about and, consequently, they found little relevance for it in their current teaching practices.

\section{Difficulties of translation equivalence}

Among the different translations of the concept 'learner autonomy' from English into Vietnamese found in Vietnamese educational documents, the word "tính", which refers to learners' characteristics of being responsible for their learning, is most favoured. In addition, the words "tự học tập" and "tự nghiên cứu" [self-study] are common in government documents. In Vietnamese, the word "tự" or "tự chủ” (self) refers to something you do on your own or by yourself. The word "chủ dộng" in Vietnamese refers to demonstrating initiative without others' support or help. It is simple to 
understand that in the interviews, participant Ha described learner autonomy as "tính tự chủ, chủ động, tự giác học của người học" [a learner's characteristic of being responsible for their own learning]. The word "sự" or "việc" refers to the behaviour/situation of the person. For example, Ngan said "sự chủ động của người học trong việc tự học là chưa có trong đối tượng này" [the behaviour of being responsible for their own learning is not for the current students]. Both terms were used by the four lecturers in the current research at various times for various reasons. For example, Bich initially defined learner autonomy as "tính chủ động tức là tự học, tự mầy mò để học" [learners' ability to study on their own without lecturers' support] as an explanation for not including any support to foster students' autonomy in her class. In her final interview, when being asked about the role of the teacher in developing learner autonomy in her class, Bich provided her definition of learner autonomy as follows (but indicated that her current students were not autonomous because she could not find these behaviours in them):

Cái sự tự chủ động học của sinh viên ây, chị nghĩ là thứ nhất nó là khả năng tự học, tự học trên lớp cũng như là ở nhà. Thứ hai là chủ động trong những tình huống của giáo viên đưa ra hoặc là chủ động trong việc thay đổi các cách dạy của giáo viên luôn. [I think it is, first, learners' ability to study on their own in the class and at home. Second, they are active in all situations that teachers give them or even autonomous in changing the teaching methods of the teacher]. Researchers (Humphreys \& Wyatt, 2014; Nguyen, 2014) have indicated that Vietnamese learners are influenced by the Confucian perspective in that there are "traditional beliefs of relational hierarchy in classrooms, where the roles of teachers and learners are rooted deeply in people's thinking" (Ho \& Crookall, 1995, p. 237). In the classes reported on for the current research, students tended to be very passive and dependent upon their teachers for learning. In these classrooms, the students were not allowed to confront their teachers directly. This would be disrespectful and cause the teacher to lose face. Consequently, schools are formed in a structure where the authority is not shared; individuality and creativity are less encouraged (Harman \& Nguyen, 2009). As a result of this system, learners tend not to be supported in developing learner autonomy during the educational process and so do not incorporate it into their pedagogy. It is probably one reason why all the interviewed teachers in the current research believed 
that learner autonomy is related to 'self-study' or 'self-regulation' and not an area for them to develop in their own classrooms.

The difficulty in using a mutually agreed idea about learner autonomy may be due to its difficult translation from English into Vietnamese. As described above, there is no consensus on what the concept of learner autonomy means in English and so it is not surprising that when this concept is translated into Vietnamese, there exist further issues that need considering. These findings will be discussed further in the following section.

\section{Discussion of Findings}

It was found in the current research that lecturers did not foster learner autonomy in their class partly due to their lack of understanding about the concept and partly due to the very powerful impact of the traditional teaching environment on them. In addition, the lecturers expressed the belief that learner autonomy did not need to be incorporated into their teaching because they believed it was innate in some students and not others, and it could not be taught. The researchers suggest that while this finding cannot be generalized to all teaching/learning situations that incorporate concepts such as learner autonomy, it is recommended that further research into how Asian countries are grappling with the incorporation of foreign-origin concepts is warranted. It is important to note that although there has been substantial literature in learner autonomy in language education in the past four decades, it is still a new concept in Vietnam. It is argued by the current researchers that an agreed understanding of the term 'learner autonomy' should be provided in policy documents which then support lecturer understanding for following through in teaching practices. The researchers would also argue that this process should occur not only with the term learner autonomy itself, but with other foreign-origin terms used in Vietnamese education.

The data in the current study indicated that lecturers' understanding and fostering of learner autonomy in their contexts failed, even though the policy is mandated by the government and their educational institutions. The major reasons for this lack of inclusion of learner autonomy include that the lecturers were reluctant to change their practices and were concerned that if they did they would not meet expected learning targets for students to successfully pass their exams. One might suggest that the focus 
here for these lecturers is on the process of teaching rather on the process of helping their students develop autonomous learning. The second area is the confusion about what is meant by the term 'learner autonomy'. Without a clear understanding of what learner autonomy means, lecturers were not provided with enough information or support on how to successfully implement it in their pedagogy. What may be inferred from these findings is that from policy to practice there exists a gap; policy makers can mandate a change, but it does not necessarily follow that lecturers will enact this change in their classrooms. This disconnection between policy and practice appeared to be due either to the lecturers' lack of awareness of the policy or that the policy was generally ignored or given low priority. For example, Bich and Ha acknowledged that they knew that there was a policy on incorporating learner autonomy but did not inquire further on what the policy meant or how to implement it into their teaching practices. Participants in the current research instead described that the pressure to implement the policy-directive concept of learner autonomy was either too difficult or impossible. To assist lecturers on how to implement mandated concepts such as learner autonomy, it is recommended that targeted workshops be provided to train lecturers in what the government means by the term and how it can be effectively applied to teaching practices.

\section{Conclusion}

This research explored how Vietnamese lecturers understood and applied the concept of learner autonomy in their pedagogy. It is important to note that there are some limitations to the study. For example, this phase of the research focused on only four lecturers. In addition, these lecturers all worked in Hanoi. It would important for future research that more lecturers, as well as lecturers in more diverse areas of Vietnam, be included to gain a greater understanding of how the mandated policy directive of incorporating the concept of learner autonomy is being addressed in general education.

In this paper, we focused on some of the challenges university lecturers may face when interpreting a concept from different linguistic and cultural backgrounds into their local context. These included the complexities of the construct of learner autonomy, the impact of traditional Vietnamese pedagogy, the difficulties of translation equivalence, and the need for teacher support to incorporate learner autonomy into existing pedagogy. 
For example, there exist various definitions of learner autonomy and attempts to apply learner autonomy in a particular context, especially research in Asian contexts (Benson, 2007). The misinterpretations of the construct appear to have negative influences on pedagogy (Esch, 1997; Little, 1991). More cross-cultural research is needed to understand how concepts can be transferred from one cultural context to another for effective use in both.

\section{References}

Baker, M. (2011). In other words: A coursebook on translation (2nd ed.). London, UK: Routledge.

Benson, P. (1997). The philosophy and politics of learner autonomy. In P. Benson \& P. Voller (Eds.), Autonomy and independence in language learning (pp. 18-34). New York, NY: Longman.

Benson, P. (2007). Autonomy in language teaching and learning.Language Teaching, 40(01), 21-40. doi: 10.1017/S0261444806003958

Calderhead, J. (1981). Stimulated recall: A method for research on teaching. British Journal of Educational Psychology, 51(2), 211-217. doi:10.1111/j.20448279.1981.tb02474.x

Dang, T. T. (2010). Learner autonomy in EFL studies in Vietnam: A discussion from sociocultural perspective. English Language Teaching, 3(2), 3-9. doi:10.5539/elt.v3n2p3

Dardjowidjojo, S. (2001). Cultural constraints in the implementation of learner autonomy: The case in Indonesia. Journal of Southeast Asian education, 2(2), 309-322.

Dickinson, L. (1987). Self-instruction in language learning. Cambridge, UK: Cambridge University Press.

Esch, E. M. (1997). Learner training for autonomous language learning. In P. Benson \& P. Voller (Eds.), Autonomy and independence in language learning (pp. 164-176). New York, NY: Longman.

Fram, S. M. (2013). The constant comparative analysis method outside of grounded theory. The Qualitative Report, 18(1), 1-25. 
SiSAL Journal Vol. 5, No. 3, September 2014, 202-216

Harman, K., \& Nguyen, T. N. B. (2009). Reforming teaching and learning in Vietnam's higher education system. In G. Harman (Ed.), Reforming higher education in Vietnam (pp. 65-86). Springer.

Ho, J., \& Crookall, D. (1995). Breaking with Chinese cultural traditions: Learner autonomy in English language teaching. System, 23(2), 235-243.

doi:10.1016/0346-251X(95)00011-8

Holec, H. (1981). Autonomy and foreign language learning. Oxford, UK: Pergamon Press.

Humphreys, G., \& Wyatt, M. (2014). Helping Vietnamese university learners to become more autonomous. ELT Journal, 68(1), 52-63. doi:10.1093/elt/ccto56

Knight, J. (2007). Internationalisation: Concepts, complexities and challenges. In J. J. F. Forest \& P. G. Altbach (Eds.), International handbook of higher education (pp.207-228). Dordrecht, Netherlands: Springer

Kvale, S., \& Brinkmann, S. (2009). Interviews: Learning the craft of qualitative research interviewing $\left(2^{\text {nd }}\right.$ ed.). Newbury Park, CA: Sage.

Lapan, S. D., Quartaroli, M. T., Riemer, F. J. (Eds.). (2012). Qualitative research: An introduction to methods and designs. San Francisco, CA: Jossey-Bass

Liamputtong, P. (2010). Performing qualitative cross-cultural research. Cambridge, UK: Cambridge University Press.

Little, D. (1991). Learner autonomy 1: Definitions, issues and problems. Dublin, Ireland: Authentik.

Lopez, G. I., Figueroa, M., Connor, S. E., \& Maliski, S. L. (2008). Translation barriers in conducting qualitative research with Spanish speakers. Qualitative Health Research, 18(12), 1729-1737. doi:10.1177/1049732308325857

Lyle, J. (2003). Stimulated recall: A report on its use in naturalistic research. British Educational Research Journal, 29(6), 861-878. doi:10.1080/0141192032000137349

Mohamed, N. (2008). I have been doing things this way for so many years; why should I change? Exploring teachers' resistance to professional learning. New Zealand Studies in Applied Linguistics, 14(1), 19-35.

Mutch, C. (2012). Curriculum change and teacher resistance. Curriculum Matters, 8, 1-8. 
SiSAL Journal Vol. 5, No. 3, September 2014, 202-216

Nguyen, T. C. L. (2010). Learner autonomy and EFL learning at the tertiary level in Vietnam (Unpublished doctoral dissertation). Victoria University of Wellington, New Zealand.

Nguyen, T. N. (2014). Learner autonomy in language learning: Teachers' beliefs (Unpublished doctoral dissertation). Queensland University of Technology, Australia.

Pham, H. H. (2006). Communicative language teaching: University within diversity. ELT Journal, 61(3), 193-201.

Pham, T. H. T. (2008). The roles of teachers in implementing educational innovation: The case of implementing cooperative learning in Vietnam. Asian Social Science, $4(1), 3-13$.

Prime Minister. (2003). Điều lệ truòng Đại học [Regulations and Principles for Universities] (No. 153/2003/QĐ-TTg issued on 30 July, 2003). Vietnam: Prime Minister.

Sutrisno, A., \& Nguyen, T. N., \& Tangen, D. (2013). Incorporating translation in qualitative studies: Two case studies in education. International Journal of Qualitative Studies in Education, (ahead of print), 1-17.

Vietnamese Assembly. (2005). Luật Giáo dục [Education Law] (No. 38/2005/QH11, issued on 14 June, 2005). Vietnam: Vietnamese Assembly.

Vygotsky, L. S. (1978). Mind in society. The development of higher psychological processes. Cambridge, MA: Harvard University Press.

Yang, H. H. (2012). Western concepts, Chinese context: A note on teaching accounting offshore. International Journal of Pedagogies and Learning, 7(10), 20-30. doi: 10.5172/ijpl.2012.7.1.20 